\author{
Marquette University \\ e-Publications@Marquette
}

$1-2018$

\title{
Who Believes in a Male God? Ideological Beliefs and Gendered Conceptualizations of God
}

Simon Howard

Marquette University, simon.howard@marquette.edu

Debra L. Oswald

Marquette University, debra.oswald@marquette.edu

Mackenzie S. Kirkman

Marquette University

Follow this and additional works at: https://epublications.marquette.edu/psych_fac

Part of the Psychology Commons

\section{Recommended Citation}

Howard, Simon; Oswald, Debra L.; and Kirkman, Mackenzie S., "Who Believes in a Male God? Ideological Beliefs and Gendered Conceptualizations of God" (2018). Psychology Faculty Research and Publications. 477.

https://epublications.marquette.edu/psych_fac/477 


\section{e-Publications@Marquette}

\section{Psychology Faculty Research and Publications/College of Arts and Sciences}

This paper is NOT THE PUBLISHED VERSION.

Access the published version via the link in the citation below.

The International Journal for the Psychology of Religion Vol. 28, No. 1 (2018): 55-70. DOI. This article is

(C) Taylor \& Francis and permission has been granted for this version to appear in e-

Publications@Marquette. Taylor \& Francis does not grant permission for this article to be further copied/distributed or hosted elsewhere without express permission from Taylor \& Francis.

\section{Who Believes in a Male God? Ideological Beliefs and Gendered Conceptualizations of God.}

Simon Howard

Department of Psychology, Marquette University, Milwaukee WI

Debra L. Oswald

Department of Psychology, Marquette University, Milwaukee WI

Mackenzie Kirkman

Department of Psychology, Marquette University, Milwaukee WI

\section{Abstract}

Recent studies have explored whether certain conceptualizations of God are associated with various attitudes and beliefs. In the current study, we examined the relationship between gendered God concepts and the belief that God is involved in one's life and religious-related rigid ideologies (i.e., religious fundamentalism and right-wing authoritarianism [RWA]). Across two studies, one conducted with religious students at a Jesuit university and the other with a national sample, we found that individuals who believed God to be male were more likely to believe that God had more control and involvement in their life, had higher levels of religious funda- mentalism and higher levels of RWAAggression (Study 1 and 2), RWA- Submission (Study 1 and 2), and RWA-Conventionalism (Study 2) than individuals with other gendered or nongendered conceptualizations of God. Implications of the 
broader impact that gendered God concepts have on social and political domains are explored. Last, limitations and future research directions are discussed.

\section{Introduction}

Religiosity has been assessed in a variety of fashions, with religious affiliation, self-reported religiosity, and religious participation and involvement (e.g., attending church, frequency of prayer) as the most common. Recently, researchers have suggested that God concepts [1] (i.e., the way in which individuals conceptualize God) may be an important, emergent, and in some cases more potent measure of religiosity relative to ones that are more commonly used (Davis, Moriarty, \& Mauch, [15]; Shariff \& Norenzayan, [42]). In this study, we are specifically interested in how one such God concept-the belief that God has a gender-is associated with the belief that God is involved in one's life and religiousrelated rigid ideologies of religious fundamentalism and right-wing authoritarianism (RWA).

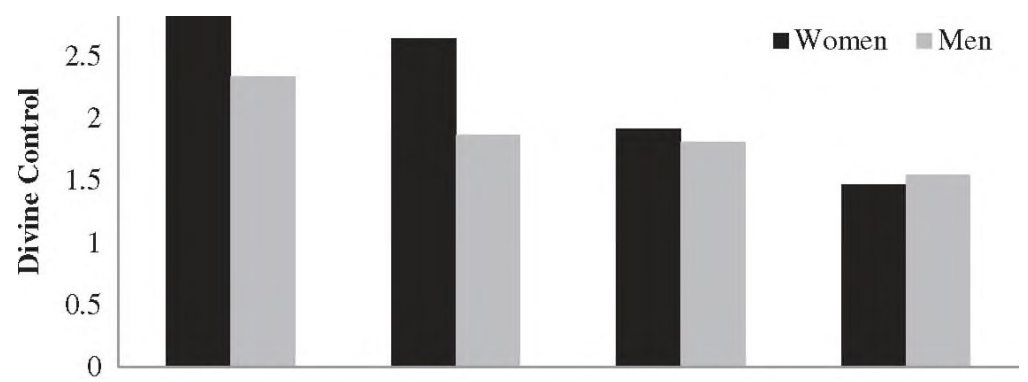

Figure 1. Interaction between God concept and gender for endorsement of divine control.

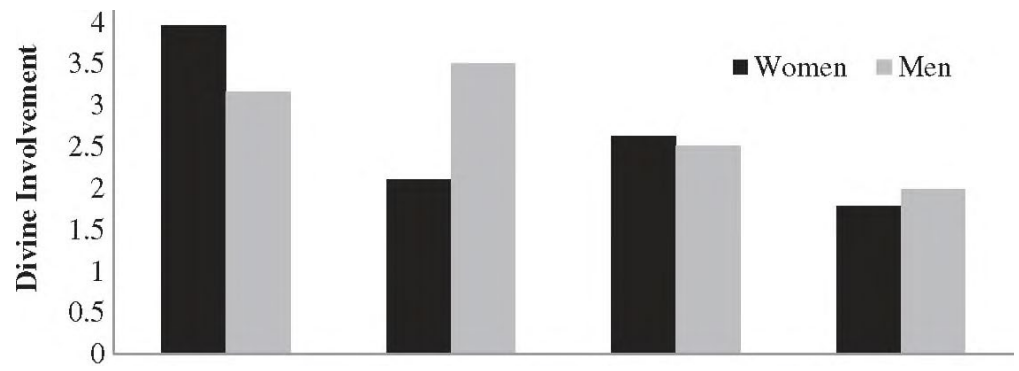

Figure 2. Interaction between God concept and gender for endorsement of divine involvement.

It has been argued that individuals' cognitive representations of God can help explain and predict their attitudes and behaviors, sometimes in ways that commonly used measures of religiosity may not (Davis et al., [15]; Shariff \& Norenzayan, [42]). For example, most studies that have explored whether trait religiosity (i.e., self-reported measures of overall religious devotion or participation in religious activity) is related to reduced cheating behavior find that religiosity does not predict the likelihood of whether someone will cheat, contrary to theoretical predictions (Nowell \& Laufer, [36]; Randolph-Seng \& Nielsen, [38]; Smith, Wheeler, \& Diener, [44]). Thus, it would appear that trait religiosity is not related to cheating behavior. However, when researchers have taken God concepts into consideration, they have found evidence suggesting otherwise. Across two studies, Shariff and Norenzayan ([42]) found that individuals who conceptualized God as angry and punishing were less likely to cheat on a math exam than those who conceptualized God as loving and compassionate. In a similar line of work, when 3-year-old children were told that an invisible supernatural agent, Princess Alice, was watching them, they were less likely to open a forbidden box than children who were not given this information 
(Clark, [12]). These results highlight the importance of diversifying the way in which religious belief is measured when exploring its relationship to various beliefs, attitudes, and behaviors.

Researchers also theorize that individuals' representations of God often reflect their explicit and implicit moral and philosophical worldviews (Froese \& Bader, [18]; Heiphetz, Lane, Waytz, \& Young, [26]). Indeed, several empirical studies support this idea and have shown that specific God concepts are related to a wide set of beliefs and attitudes. For example, benevolent and loving views of God are positively correlated with support for social and economic justice (e.g., government should distribute wealth more equitably; Froese \& Bader, [18]), whereas authoritarian conceptualizations of God (i.e., controlling, commanding, punishing) are related to absolutist views regarding sexual morality (Bader \& Froese, [8]), a desire for more integration between the church and the state, and beliefs that that God takes sides in world affairs (Froese \& Bader, [17], [18]). Other research has shown that an active representation of God (i.e., active interest in human affairs) is also positively correlated to conservative political attitudes and more conservative views regarding sexual morality (Bader \& Froese, [ 8]).

Although researchers have utilized a broad range of God concepts, the studies just referenced highlight the conceptualizations that are used the most often (i.e., benevolent and loving, authoritarian and punishing, and active or passive). Surprisingly, despite the fact that God is often referred to with the male pronoun "He" and that more than half of individuals who self-report believing in God say they believe in a gendered God (Harris Poll, [25]), few researchers have utilized gendered God concepts in their studies. The few studies that have been conducted have found that Americans with maternal representations of God (i.e., God as motherly) were more likely to have politically liberal views and attitudes. For example, these individuals were more likely to vote Democrat (Greeley, [20]), support environmental protection (Greeley, [21]), and oppose the death penalty (Greeley, [20]). Most recently, research has found that gendered conceptions of God, specifically male concepts of God, are related to preferences for traditional gender roles (e.g., believing men are better suited for politics; Cassese \& Holman, [10]; Whitehead, [49]), political conservatism (Cassese \& Holman, [10]), and negative attitudes toward same-sex marriage (Whitehead, [50]).

Although this and other work provides support for the notion that gendered images of God are associated with beliefs and attitudes, the relationship between gendered conceptualizations of God and beliefs and attitudes outside of the realm of politics and gender traditionalism remains unexplored. In this article we aim to advance the God concept literature by examining the relationship between gendered God concepts and ideological beliefs that have yet to be examined. In particular, we examine whether male conceptualizations of God are related to other religious beliefs (i.e., divine control and divine involvement) and rigid ideologies (i.e., religious fundamentalism and RWA).

\section{Divine control and divine involvement}

Perception of divine control and divine involvement is the extent to which an individual perceives that God has authority over the course, direction, and outcomes of one's life (Schieman, [40]; Schieman, Pudrovska, \& Milkie, [41]). An all-powerful and all-knowing God(s) that is the primary force governing life is a fundamental feature across most religions (Atran \& Norenzayan, [ 7]). Individuals with high levels of perceived divine control and divine involvement tend to rely on God not only for decision making but also as a source for solutions to problems. Although we know that there are individual differences in the extent to which individuals believe that God has control and involvement in their life, 
we do not know if these beliefs vary based on how individuals conceptualize God's gender. Because conceptualizations of God as male reflects how that person perceives power, ability, status, and hierarchy (Froese \& Bader, [18]), individuals who believe God to be a male versus something else may also believe God has more control (i.e., divine control) and involvement (i.e., divine involvement) in their lives.

\section{Rigid ideologies (religious fundamentalism and RWA)}

Rigid ideological beliefs such as religious fundamentalism and RWA are often associated with religiosity (B. Altemeyer \& Hunsberger, [ 2]; R. A. Altemeyer, [ 4], [ 5], [ 6]). Whereas religious fundamentalism is a close-minded set of beliefs contingent on the belief in the absolute authority of a sacred religious text or teachings of a particular religious leader, prophet, and/or deity (B. Altemeyer \& Hunsberger, [2]), RWA is characterized as adherence to a broad set of traditional and moral values that need to be both maintained and protected. RWA comprises three related components: conventionalism, submission to authority, and authoritarian use of aggression (Rowatt, Shen, LaBouff, \& Gonzalez, [39]). Right-wing authoritarians agree that people should adhere to social conventions and submit to legitimate authorities. Right-wing authoritarians also condone the use of aggression against people they perceive to disobey authorities, violate laws, or deviate from social conventions. Right-wing authoritarians tend to be high in religiosity and have high levels of religious engagement (e.g., private prayer, attending religious services, and reading religious text; Altemeyer \& Hunsberger, [ 2]; Altemeyer, [4], [5]). People who are high in religious fundamentalism also tend to be high in RWA (Altemeyer \& Hunsberger, [ 2]).

The way that individuals conceptualize God's gender may be associated with both religious fundamentalism and RWA. Because those high in religious fundamentalism are more likely to have a strict and literal interpretation of specific scriptures, dogmas, or ideologies, these individuals may be more likely to have a male conceptualization of God, especially considering God is often referred to with male pronouns by religious leaders and religious texts. Regarding gendered conceptualizations of God and RWA, individuals with male conceptualizations of God may also have higher levels of RWA than individuals with other conceptualizations of God. As just stated, the ways in which individuals conceptualize God reflect how that person perceives power, ability, status, and hierarchy (Froese \& Bader, [18]) and provides insight in how they understand the world. The belief that God is male versus something else reflects a belief in male authority, and because men traditionally hold positions of authority and power in patriarchal societies, a male image of God may serve to legitimatize the social and political authority of men in society (Christ, [11]; Daly, [14]). This may explain why male conceptualizations of God are associated with less egalitarian beliefs surrounding gender (e.g., believing men are better suited for politics; Cassese \& Holman, [10]; Whitehead, [49]) and negative attitudes toward same-sex marriage (Whitehead, [50]). Both gender equality and same-sex marriage equality can be viewed as threats to conservative or traditional (patriarchal) values. Because RWA and male conceptualizations of God are correlated to value violating prejudice (e.g., antigay prejudice; Crawford, Brandt, Inbar, \& Mallinas, [13]; Whitehead, [50]), it is important to explore whether individuals with male conceptualizations of God are higher in RWA than those with other conceptualizations. 


\section{Hypotheses}

In light of recent theorizing and research on the influence of gendered God concepts on beliefs and attitudes, we hypothesize that individuals with male conceptualizations of God will (a) have stronger beliefs regarding the amount of control (i.e., divine control) and involvement (i.e., divine involvement) God has in their life, (b) have higher levels of religious fundamentalism, and (c) have higher levels of RWA (i.e., RWA-Aggression, RWA-Submission, RWA-Conventionalism) relative to individuals with other gender conceptualizations of God.

\section{Study 1}

\section{Method}

\section{Participants}

Two hundred four undergraduate students from a midsize Jesuit university in the Midwest participated in the study. Of these participants, data from five were removed from the analyses because of unreasonably fast responding (defined as a completion time as less than one third of the median completion time). An additional eight participants were removed for having incomplete surveys (these individuals each completed less than $44 \%$ of the study items). One participant was removed from the analyses due to illogical response patterns. The remaining 190 participants were included in the analyses.

Approximately half of the participants were women (95 women, 89 men). With regards to ethnicity, 67.9\% $(n=129)$ identified as Caucasian, 3.7\% $(n=7)$ as African American, $13.2 \%(n=25)$ as Asian American, $7.9 \%(n=15)$ as Latina/o, $1.1 \%(n=2)$ as Middle Eastern, and 6.3\% $(n=12)$ as another ethnicity. The majority indicated they were heterosexual $(93.7 \%, n=178)$. The mean age of participants was $18.86(S D=1.01)$. With regards to religion, $67.9 \%(n=129)$ identified as Catholic, $4.7 \%$ $(n=9)$ as Evangelical Christian, 5.8\% $(n=11)$ as Mainline Protestant, 2.6\% $(n=5)$ as Orthodox Christian, $1.6 \%(n=3)$ as Muslim, 2.1\% $(n=4)$ as Hindu, and 2.1\% $(n=4)$ as another religion; $10.5 \%(n=20)$ did not identify with any religion.

\section{Measures}

\section{Divine control}

Divine Control is a five-item scale that measures the belief that God has a plan and is in control of people's lives (Schieman et al., [41]). Items are on a scale of 1 (strongly disagree) to 4 (strongly agree). It includes statements such as "God has decided what your life shall be." Due to an input error, one item was missing ("You depend on God for help and guidance") for half the participants. The Cronbach alpha varied based on the inclusion of this item; it was.76 without the missing item and.83 with this item. The mean of these five items was computed; higher scores indicate greater endorsement of divine control.

\section{Divine involvement}

Divine Involvement is a three-item scale that measures the belief that God is involved in and concerned about an individual's well-being and personal affairs (Schieman, [40]). These items are on a scale of 1 (strongly disagree) to 5 (strongly agree). It includes statements such as "God is concerned with my personal well-being." The Cronbach alpha was.86. The mean of these three items was computed; higher scores indicate greater endorsement of divine involvement. 


\section{Religious fundamentalism}

The Religious Fundamentalism scale (Altemeyer \& Hunsberger, [ 3]) is a 12-item scale measuring the belief that one's religion has the basic, unerring truth about God. These items are on a scale of -4 (very strongly disagree) to +4 (very strongly agree). It includes statements such as "God has given humanity a complete, unfailing guide to happiness and salvation, which must be totally followed." The Cronbach alpha was.89. Scores on this subscale were converted to a 1-to-9 scale, and the mean was computed; higher scores indicate greater endorsement of religious fundamentalism.

\section{RWA}

The Right-Wing Authoritarianism Scale is a 20-item scale assessing beliefs related to authority figures. It includes statements such as "Our country will be destroyed someday if we do not smash the perversions eating away at our moral fiber and traditional beliefs." These items are on a scale of -4 (very strongly disagree) to +4 (very strongly agree). Scores on this subscale were converted to a 1-to-9 scale, and the mean was computed; higher scores indicate greater endorsement of RWA. The Cronbach alpha for the overall score was.90. Three subscales were computed based on the theoretical subscales of conventionalism (nine items), authority aggression (five items), and authority submission (six items), consistent with arguments by Rowatt et al. ([39]). The Cronbach alphas for the subscales were.80,.75, and.84, respectively.

\section{God concepts}

Participants' conceptualization of God was measured in two different ways. They were first asked open-ended questions about whether they believed in God and whether there was one God or many gods. They were then asked, "Based on your personal understanding of God, do you think of God as" [check only one option] a male, a female, both male and female, something else, or do not know. This set of response options was based on Jensen's ([29]) coding system for gendered conception of God.

\section{Demographics}

Participants completed demographics including age, ethnicity, sexual orientation, religious affiliation, and gender.

\section{Procedure}

Participants were recruited from a psychology department subject pool and participated for partial course credit. The survey was programmed using Qualtrics, an online survey program. Participants were provided a link to the survey and completed it at a time and location of their choice. Participants were first asked about their view of God. The other measures were randomly presented with demographics completed last. Upon completion of the survey, participants were given a password and then directed to another, unrelated page to enter their information to receive participation credit.

\section{Results}

One hundred sixty-five (86.8\%) participants reported that they believed in God. The majority believed in one God (84.2\%), with $2.6 \%$ believing in multiple Gods and $7.9 \%$ believing in no God; $4.7 \%$ were unsure or believed God was something else. The majority of participants reported that they personally believed God to be a male ( $n=129,67.9 \%$ ), whereas smaller numbers of participants reported a female conceptualization of God $(n=3,1.6 \%)$, both a male and female conceptualization of God 
( $n=11,5.8 \%)$, something else ( $n=35,18.19 \%)$, or they didn't know $(n=5,2.6 \%)$. Seven participants did not answer the question regarding their personal gendered God concept.

For exploratory purposes, we examined the association between participant gender and gendered conceptualizations of God (grouped as male conceptualization of God vs. all other conceptualizations of God). Participant gender was not associated with gendered conceptualization of God, $\chi^{2}(1, N$ $=177)=2.15, p=.14$. For the female participants, $75.6 \%(n=68)$ viewed God as a male, and $24.4 \%$ $(n=22)$ had a nonmale representation of God. Among the male participants, $65.5 \%(n=57)$ viewed God as a male, and 34.5\% $(n=30)$ had a nonmale representation of God.

Bivariate correlations between the variables were examined. The ideological variables were all positively correlated $(r s=.53-.80)$. Means and standard deviations are presented in Table 1.

Table 1 . Study 1 correlations between ideological variables.

\begin{tabular}{|c|c|c|c|c|c|c|}
\hline & $\begin{array}{l}\text { Divine } \\
\text { Involvemen } \\
\mathrm{t}\end{array}$ & $\begin{array}{l}\text { Divine } \\
\text { Contro } \\
\text { I }\end{array}$ & $\begin{array}{l}\text { Religious } \\
\text { Fundamentalis } \\
\mathrm{m}\end{array}$ & $\begin{array}{l}\text { RWA - } \\
\text { Aggressio } \\
n\end{array}$ & $\begin{array}{l}\text { RWA - } \\
\text { Submissio } \\
n\end{array}$ & $\begin{array}{l}\text { RWA - } \\
\text { Conventionalis } \\
\mathrm{m}\end{array}$ \\
\hline $\begin{array}{l}\text { Divine } \\
\text { Involvement }\end{array}$ & $3.47(1.08)$ & $.80 *$ & $.68 *$ & $.44 * *$ & $.41 * *$ & $.46 * *$ \\
\hline Divine Control & & $\begin{array}{l}2.32 \\
(.70)\end{array}$ & $.76^{*}$ & $.46 * *$ & $.47 * *$ & $.51 * *$ \\
\hline $\begin{array}{l}\text { Religious } \\
\text { Fundamentalis } \\
\mathrm{m}\end{array}$ & & & $4.09(1.47)$ & $.51 * *$ & $.55^{* *}$ & $.66 * *$ \\
\hline $\begin{array}{l}\text { RWA- } \\
\text { Authoritarian } \\
\text { Aggression }\end{array}$ & & & & $\begin{array}{l}4.79 \\
(1.60)\end{array}$ & $.63 * *$ & $.47 * *$ \\
\hline $\begin{array}{l}\text { RWA- } \\
\text { Submission }\end{array}$ & & & & & $\begin{array}{l}4.19 \\
(1.32) \\
\end{array}$ & $.66 * *$ \\
\hline $\begin{array}{l}\text { RWA- } \\
\text { Conventionalis } \\
\mathrm{m}\end{array}$ & & & & & & $3.34(1.28)$ \\
\hline
\end{tabular}

Note. Means and standard deviations are presented on the diagonal.

${ }^{*} p<.01 ; * p<.001$.

To examine how people who view God as a male differ from those who have a nonmale representation of God, we collapsed the participants who viewed God as anything other than male into one group (resulting in a sample of 49). We conducted a series of 2 (god concept: male or other) $\times 2$ (participant gender) analyses of variance (ANOVAs).

The ANOVAs resulted in significant main effects for gendered perception of God on all variables of interest. Specifically, those with a male view of God were higher on divine involvement, $F(1$, $149)=8.15, p<.01$, partial $\eta^{2}=.04$; divine control, $F(1,164)=7.26, p<.01$, partial $\eta^{2}=.05$; and religious fundamentalism, $F(1,158)=7.39, p<.01$, partial $\eta^{2}=.05$. In contrast, there were no significant main effects for participant gender for divine involvement, $F(1,164)=.114, p=.74$, partial $\eta^{2}=.001$; divine control, $F(1,149)=1.07, p=.30$, partial $\eta^{2}=.01$; or religious fundamentalism, $F(1$, 
$158)=.05, p=.83$, partial $\eta^{2}<.001$. Nor were there any significant interactions between participant gender and gendered perception of God for divine involvement, $F(1,164)=2.18, p=.14$, partial $\eta^{2}=.01$; divine control, $F(1,149)=.98, p=.14$, partial $\eta^{2}=.02$; or religious fundamentalism, $F(1$, $158)=1.21, p=.27$, partial $\eta^{2}<.01$. See Table 2 for mean differences between the two groups.

A 2 (participant gender) $\times 2$ (God concept) multivariate analysis of variance was conducted for the three Right-Wing Authoritarianism Scale subscales. The multivariate main effect for God Concept was significant, Wilks's $\lambda=.93, F(3,161)=4.09, p<.01$, partial $\eta^{2}=.07$. The multivariate main effect of participant gender, Wilks's $\lambda=.99, F(3,161)=.48, p=.70$, partial $\eta^{2}<.01$, and the interaction, Wilks's $\lambda$ $=1.0, F(3,161)=.19, p=.91$, partial $\eta^{2}<.01$, were not significant. Follow-up ANOVAs for the main effect of God Concept indicated that participants with a male image of God were higher for Authoritarian Aggression, $F(1,163)=12.14, p<.01$, partial $\eta^{2}=.07$, and Submission, $F(1$, $163)=5.89, p=.02$, partial $\eta^{2}=.04$, but not for Conventionalism, $F(1,163)=2.58, p=.11$, partial $\eta^{2}=.016$.

\section{Discussion}

The results from Study 1 provide some initial evidence that gendered conceptualizations of God are associated with individuals' other religious beliefs and rigid ideologies. Specifically, we found that when God is conceptualized as male (vs. something else), individuals believe that God has more control over their lives and is more involved in their lives. In addition, individuals who conceptualize God as male are also more likely to be religious fundamentalists and higher in RWA than those who conceptualize God as female, conceptualize God as both male and female, or say they do not know God's gender. In other words, individuals who believe God to be male are more likely to believe religious texts, teachings, leaders, and God are absolute authorities and submit to authorities perceived as legitimate. Of interest, however, we did not find that individuals who believed God to be male had higher levels of conventionalism than individuals who had other gendered conceptualizations of God. This may be explained in part by the sample being millennial, college-aged Catholics. The content of the items included in the component of conventionalism mostly deal with sexually restrictive sentiments (e.g., disagreeing with "There is nothing wrong with premarital sexual intercourse"), and despite how these millennials conceptualize God, they may have similar views regarding sexually restrictive sentiments. Young Catholics tend to be more open in regards to questions about topics such as premarital sex, and they are one of the most likely groups to engage in premarital sex (Featherstone, [16]). Future research, however is necessary to explore this possibility. Last, it is important to note that these findings did not differ by gender of the participant.

\section{Study 2}

Because the participants in Study 1 were college students enrolled at a Jesuit university located in the Midwest, we administered a replication of the study with a sample that was more representative of the general population and more diverse in terms of age and Christian sect. Furthermore, Study 2 allowed us to collect data from participants in a context (presumably) not as religious as a Catholic institution of higher learning. Past research on religious contextual priming has shown that being in presence of religious institutions (e.g., church) is enough to influence individuals' attitudes and beliefs (LaBouff, Rowatt, Johnson, \& Finkle, [32]). 
Table 2: Study 1 mean differences between participants with a male image of God and participants with a "nonmale" image of God

\begin{tabular}{|l|l|l|}
\hline & Male Image of God & Nonmale Image of God \\
\hline Divine Involvement & $3.65(0.97)$ & $3.17(1.14)$ \\
\hline Divine Control & $2.47(0.66)$ & $2.10(0.70)$ \\
\hline Religious Fundamentalism & $4.35(1.35)$ & $3.69(1.53)$ \\
\hline RWA - Authoritarian Aggression & $5.06(1.58)$ & $4.15(1.46)$ \\
\hline RWA - Authoritarian Submission & $4.35(1.28)$ & $3.83(1.37)$ \\
\hline RWA Conventionalism & $3.43(1.22)$ & $3.12(1.41)$ \\
\hline
\end{tabular}

\section{Method}

\section{Participants}

Three hundred ninety-four participants completed the study online via Amazon Mechanical Turk (MTurk). MTurk is an online crowdsourcing service where anonymous workers complete online experiments for monetary compensation. Samples acquired through MTurk have been shown to produce reliable high-quality data and are more diverse than typical American college samples (Buhrmester, Kwang, \& Gosling, [ 9]). Of the 394 people who completed the study, 21 completed the survey in less than one third (190 s) of the median completion time (569.00 s). These participants were deemed to have unreasonably fast completion times and were removed from the following analyses..

Approximately half (55.2\%) of the participants were women (206 women, 166 men). With regards to ethnicity, 75.3\% ( $n=281)$ identified as Caucasian, 7.5\% $(n=28)$ as African American, 7.8\% $(n=29)$ as Asian American, 4.6\% ( $n=17)$ as Latina/o, and 2.1\% $(n=8)$ as biracial or multiracial; $2.7(n=10)$ indicated another ethnicity. The majority indicated they were heterosexual $(90.3 \%, n=337)$. The mean age of the participants was $39.14(S D=13.12)$. With regards to religion, $18.0 \%(n=67)$ identified as Evangelical Christian, $17.7 \%(n=66)$ as Catholic, $12.6 \%(n=47)$ as Mainline Protestant, $2.1 \%(n=8)$ as Jewish, $1.3 \%(n=5)$ as Buddhist, 1.1\% $(n=4)$ as Orthodox Christian, 1.1\% $(n=4)$ as Muslim, 1.1\% $(n=4)$ as Mormon, $8 \%(n=3)$ as Hindu, and 3.2\% $(n=12)$ as another religion; $11.5 \%(n=43)$ did not identify with any religion. Fifty-one individuals identified as atheist (13.7\%), and 52 indicated being agnostic (13.9\%).

\section{Measures}

All measures used for Study 2 were identical to those used in Study 1, so we do not provide detailed description for each measure. The Cronbach alphas for Study 2 were all strong: divine control, $\alpha=.91$; divine involvement, $\alpha=.91$; religious fundamentalism, $\alpha=.96$; RWA (Aggression, $\alpha=.94$; Submission, $\alpha$ =.90; Conventionalism, $\alpha=.93$ ).

\section{Demographics}

Participants completed demographics including age, ethnicity, sexual orientation, religious affiliation, and gender.

\section{Procedure}

Participants were recruited from Mturk and were compensated $\$ 0.50$ for their participation. The survey was programmed using Qualtrics, an online survey program. Participants were provided a link 
to the survey and completed it at a time and location of their choice. Participants were randomly presented the surveys with demographics completed last. The items asking about belief in God and conceptualization of God's gender were included with the demographics and thus were completed last.

\section{Results}

Two hundred nine (56.0\%) participants reported that they believed in God, $96(25.7 \%)$ indicated that they did not believe in God, and 59 (15.8\%) reported being unsure if there is a God. The majority believed in one God ( $n=194,52 \%)$, with 19 (5.1\%) believing in multiple Gods; the rest believed in no God $(n=81,21.7 \%)$, were unsure $(n=72,19.3 \%)$, or had another belief $(n=6,1.6 \%)$.

The majority of our participants reported that they personally believed God to be a male ( $n=143$, $38.3 \%)$, whereas smaller numbers of participants conceptualized God as a female $(n=4,1.1 \%)$, had both a male and female conceptualization of $\operatorname{God}(n=31,8.3 \%)$, reported something else $(n=117$, $31.4 \%)$, or indicated they didn't know ( $n=78,20.9 \%)$. Given the larger sample sizes for the different gendered representations of God, we were able to have four God concept groups: those with a male God concept $(n=143)$, those with a female or female + male God concept $(n=35)$, those who reported God being something else $(n=117)$, and a fourth group who reported "don't know" $(n=78)$.

We again examined the association between participant gender and conceptualizations of God. Participant gender was not associated with gendered conceptualization of God, $\chi^{2}$ ( 3, $N=372)=5.16, p=.16$. For the male participants, $34.9 \%(n=58)$ viewed God as a male, $7.2 \%$ ( $n=12$ ) had a female or female + male conceptualization of God, 36.7\% ( $n=61)$ reported something else, and $21.1 \%(n=35)$ indicated that they didn't know. Among the female participants, $41.3 \%(n=85)$ viewed God as a male, $11.2 \%(n=23)$ had a female or female + male conceptualization of God, $27.2 \%$ $(n=56)$ reported something else, and $20.4 \%(n=42)$ indicated that they didn't know.

Given the larger number of people who reported not believing in God in Study 2 compared to Study 1, we investigated the association between believing in God (compared to not believing in God or being unsure) and gendered belief in God. A chi-square test of independence was significant, $\chi^{2}(6, N=364)$ $=85.89, p<.01$. Of the participants who believed in God, more than half reported that they believed God to be male ( $n=114,54.55 \%)$, with only $11.0 \%(n=23)$ reporting that God was female or female + male, $27.3 \%$ reported God was something else $(n=57)$, and $7.2 \%(n=15)$ reported that they didn't know in regards to God's gender. Of the people who reported that they did not believe in a God, only $15.6 \%(n=15)$ reported that God was a male, $5.2 \%(n=5)$ reported that God was female or female + male, 33.3\% reported that God was something else $(n=32)$, and almost half reported they didn't know in regards to God's gender $(45.8 \%, n=44)$. Of those who were unsure if they believed in God, $22.0 \%$ $(n=13)$ had a male conceptualization of God, $8.5 \%(n=5)$ had a female or female + male conceptualization of God, 43.4\% ( $n=25)$ had something else for an image of God, and 27.1\% $(n=16)$ reported they didn't know God's gender. These findings highlight that the belief that God has a gender is more strongly held by those who believe in God than those who do not believe in God. However, although individuals who do not believe in God or are unsure if God exists are less likely to gender God relative to believers, they are still more likely to conceptualize God as a male than a female.

Bivaraite correlations between the variables were examined. As in Study 1, the ideological variables were all positively correlated. Means and standard deviations are presented in Table 3. 
Table 3. Study 2 correlations between ideological variables.

\begin{tabular}{|c|c|c|c|c|c|c|}
\hline & $\begin{array}{l}\text { Divine } \\
\text { Involvemen } \\
\mathrm{t}\end{array}$ & $\begin{array}{l}\text { Divine } \\
\text { Contro } \\
\text { I }\end{array}$ & $\begin{array}{l}\text { Religious } \\
\text { Fundamentalis } \\
\mathrm{m}\end{array}$ & $\begin{array}{l}\text { RWA- } \\
\text { Aggressio } \\
n\end{array}$ & $\begin{array}{l}\text { RWA- } \\
\text { Submissio } \\
n\end{array}$ & $\begin{array}{l}\text { RWA- } \\
\text { Conventionalis } \\
\mathrm{m}\end{array}$ \\
\hline $\begin{array}{l}\text { Divine } \\
\text { Involvement }\end{array}$ & 2.89 (1.49) & $.88 *$ & $.83^{*}$ & $.59 * *$ & $.58 * *$ & $.61 * *$ \\
\hline Divine Control & & $\begin{array}{l}2.13 \\
(.95)\end{array}$ & $.85^{*}$ & $.64 * *$ & $.63^{* *}$ & $.65^{* *}$ \\
\hline $\begin{array}{l}\text { Religious } \\
\text { Fundamentalis } \\
\mathrm{m}\end{array}$ & & & $4.00(2.46)$ & $.69 * *$ & $.71 * *$ & $.80 * *$ \\
\hline $\begin{array}{l}\text { RWA- } \\
\text { Aggression }\end{array}$ & & & & $\begin{array}{l}4.09 \\
(2.52)\end{array}$ & $.83 * *$ & $.72 * *$ \\
\hline $\begin{array}{l}\text { RWA- } \\
\text { Submission }\end{array}$ & & & & & $\begin{array}{l}3.92 \\
(2.15) \\
\end{array}$ & $.84^{* *}$ \\
\hline $\begin{array}{l}\text { RWA- } \\
\text { Conventionalis } \\
\mathrm{m}\end{array}$ & & & & & & $3.66(2.19)$ \\
\hline
\end{tabular}

Note. Means and standard deviations are presented on the diagonal.

${ }^{*} p<.01 ; * p<.001$.

To examine how people who view God as a male differ from those who have a nonmale conceptualization of God, we conducted a series of 4 (god concepts) $\times 2$ (participant gender) ANOVAs. Group means and all pairwise comparisons are reported in Table 4.

Table 4. Study 2 mean differences between gender of God image groups.

\begin{tabular}{|l|l|l|l|l|}
\hline & Male Image & $\begin{array}{l}\text { Female and Male }+ \\
\text { Female Image }\end{array}$ & Something Else & Don't Know \\
\hline Religious Fundamentalism & $5.27(2.37)_{\mathrm{a}}$ & $4.18(2.55)_{\mathrm{b}}$ & $3.25(2.23)_{\mathrm{b}, \mathrm{c}}$ & $2.70(1.74)_{\mathrm{c}}$ \\
\hline Divine control & $2.62(0.88)_{\mathrm{a}}$ & $2.38(0.97)_{\mathrm{a}}$ & $1.86(0.84)_{\mathrm{b}}$ & $1.51(0.70)_{\mathrm{c}}$ \\
\hline Divine Involvement & $3.65(1.35)_{\mathrm{a}}$ & $3.03(1.39)_{\mathrm{b}}$ & $2.57(1.42)_{\mathrm{b}}$ & $1.88(1.13)_{\mathrm{c}}$ \\
\hline RWA-Aggression & $5.41(2.36)_{\mathrm{a}}$ & $4.20(2.76)_{\mathrm{b}}$ & $3.25(2.20)_{\mathrm{b}, \mathrm{c}}$ & $2.89(2.00)_{\mathrm{c}}$ \\
\hline RWA-Submission & $5.08(2.08)_{\mathrm{a}}$ & $3.70(2.09)_{\mathrm{b}}$ & $3.14(1.87)_{\mathrm{b}}$ & $3.06(1.70)_{\mathrm{b}}$ \\
\hline RWA-Conventionalism & $4.63(2.22)_{\mathrm{a}}$ & $3.76(2.32)_{\mathrm{a}, \mathrm{b}}$ & $3.08(1.94)_{\mathrm{b}}$ & $2.70(1.66)_{\mathrm{b}}$ \\
\hline
\end{tabular}

Note. Different subscripts represent significant differences (Tukey's honestly significant difference, $p<.05$ ). For all variables with the same letter, the difference between the means is not statistically significant. If two variables have different letters, they are significantly different.

For Divine Control, there was a significant main effect of God concept, $F(3,364)=31.70, p<.01$, partial $\eta^{2}=.21$. Tukey's honestly significant difference (HSD; $p<.05$ ) post hoc tests indicate that those who believe God is a male or those who believe God is a female or female + male were higher on divine control than those who believed God's gender to be something else or reporting not knowing. There was also a main effect for participant gender, $F(1,364)=9.82, p<.01$, partial $\eta^{2}=.03$, such that women $(M=2.28, S D=.99)$ reported higher levels of divine control than did men $(M=1.94, S D=.87)$. 
However, both main effects were qualified by a God Concept $\times$ Participant Gender interaction, $F(3$, $364)=3.23, p<.01$, partial $\eta^{2}=.03$ (see Fig. 1). Simple effect tests indicate that the women were higher than men for divine control only when they had a male image of God

$\left(M_{\text {Men }}=2.34, S D=.87 ; M_{\text {Women }}=2.82, S D=.84\right), F(1,143)=10.85, p<.01$, partial $\eta^{2}=.07$, or a female and female + male image of $\operatorname{God}\left(M_{\text {Men }}=1.87, S D=.90 ; M_{\text {women }}=2.64, S D=.92\right), F(1$, 33) $=5.70, p<.01$, partial $\eta^{2}=.15$. However, there were no participant gender differences if the participants reported an image of God as "something else"

$\left(M_{\text {Men }}=1.81, S D=.80 ; M_{\text {Women }}=1.92, S D=.90\right), F(1,117)=.50, p=.48$, or that they "didn't know" $\left(M_{\text {Men }}=1.55, S D=.77 ; M_{\text {Women }}=1.47, S D=.65\right), F(1,77)=.28, p=.60$.

A similar pattern of results was found for Divine Involvement. There was a significant main effect of god concept, $F(3,364)=29.62, p<.01$, partial $\eta^{2}=.20$. Tukey HSD $(p<.05)$ post hoc tests indicate that those who believe God is a male also believed God had more divine involvement in their life. Those who conceptualized God as female or female + male and "something else" were higher than those who reported they didn't know. Group means and all pairwise comparisons are reported in Table 4. There was also a main effect for participant gender, $F(1,364)=11.02, p<.01$, partial $\eta^{2}=.03$, such that women $(M=3.11, S D=1.55)$ reported higher levels of divine control than did men $(M=2.60, S D=1.37)$. However, both main effects were qualified by a God Concept $\times$ Participant Gender interaction, $F(3,364)=4.42, p<.01$, partial $\eta^{2}=.04$ (see Fig. 2). Simple effect tests indicate that the women were higher than men for divine involvement only when they conceptualized God as male $\left(M_{\text {Men }}=3.17, S D=1.36 ; M_{\text {Women }}=3.97, S D=1.25\right), F(1,143)=13.42, p<.01$, partial $\left.\eta^{2}=.09\right)$ or a female and female + male image of $G o d\left(M_{\text {Men }}=2.11, S D=1.14 ; M_{\text {women }}=3.51, S D=1.27\right), F(1$, 33) $=10.14, p<.01$, partial $\eta^{2}=.24$. There were no participant gender differences if the participants reported an image of God as "something else" ( $\left.M_{\text {Men }}=2.51, S D=1.36 ; M_{\text {women }}=2.63, S D=1.50\right), F(1$, $117)=.22, p=.64$, or that they "didn't know" ( $\left.M_{\text {Men }}=1.99, S D=1.16 ; M_{\text {Women }}=1.79, S D=1.12\right), F(1$, 77) $=.57, p=.45$.

For Religious Fundamentalism there was a main effect of God concept, $F(3,364)=26.05, p<.01$, partial $\eta^{2}=.18$. Tukey's HSD $(p<.05)$ post hoc tests indicate that those who believe God is a male were the highest on religious fundamentalism than all other groups. Those who indicated "not knowing" were lower than all other groups except those who reported "something else." Group means and all pairwise comparisons are reported in Table 4. There was also a significant main effect for participant gender, $F(1,364)=5.07, p=.01$, partial $\eta^{2}=.01$, such that men $(M=3.56, S D=2.25)$ scored lower than did women $(M=4.35, S D=2.58)$. There was not a significant interaction between participant gender and god concept, $F(3,364)=1.09, p=.36$, partial $\eta^{2}<.01$.

A 2 (participant gender) $\times 4$ (god concept) MANOVA was conducted for the three Right-Wing Authoritarianism Scale subscales. There was a multivariate main effect of God Concept, Wilks's $\lambda$ $=.79, F(9,881.16)=9.35, p<.01$, partial $\eta^{2}=.07$. The multivariate main effect for participant gender was significant, Wilks's $\lambda=.98, F(3,362)=2.74, p=.04$, partial $\eta^{2}=.02$; however, none of the follow-up ANOVAs were significant, so this is not discussed further. The multivariate interaction between participant gender and God Concept, Wilks's $\lambda=.97, F(9,881.16)=1.44, p=.17$, partial $\eta^{2}=.01$.

Follow-up ANOVAs and Tukey HSD $(p<.05)$ post hoc tests indicate that for Authoritarian Aggression, $F(3,364)=26.45, p<.01$, partial $\eta^{2}=.18$, those who believe God is a male were the highest 
on authoritarian aggression than all other groups. Those who indicated "not knowing" were lower than all other groups except those who reported "something else." For Submission, $F(3$, $364)=26.79, p<.01$, partial $\eta^{2}=.18$, those with a male image of God were higher than all other groups. Conventionalism also differed between the God Concept groups, $F(3,364)=19.04, p<.01$, partial $\eta^{2}=.14$, such that individuals with a male image of God were higher in conventionalism than those who reported not knowing or God as something else. Group means and all pairwise comparisons are reported in Table 4.

\section{Discussion}

Using a sample that was more reflective of the general public in terms of age and religious diversity, we replicated the results found with our religious college sample (i.e., Study 1). Gendered conceptualizations of God-in particular, male conceptualizations-are related to higher beliefs in divine control, divine involvement, religious fundamentalism, and RWA. However, although our results from Study 2 closely mirror those of Study 1, we did find a few minor differences between the two. First, we found that women were higher in religious fundamentalism relative to men in Study 2; this was not the case in Study 1. Although we did not find this gender difference in Study 1, gender differences in religiosity are common in the United States, and research consistently demonstrates that women are generally more religious than men (i.e., "religious gender gap"), particularly among Christians (Pew Research Center, [37]), and are higher in religious fundamentalism (Kelley \& De Graaf, [31]; Trzebiatowska \& Bruce, [47]) than men. In addition, women are more likely to adopt a literal interpretation of the Bible relative to men (Village, [48]).

Second, we found evidence that female + male conceptualizations of God,[2]which can be thought of as an androgynous conceptualization of God, were associated with higher beliefs of divine involvement and divine control for women in Study 2. Although we predicted that only male images of God would result in higher beliefs in divine control and divine involvement, it appears that for women, androgynous conceptualizations of God may also be associated with higher beliefs in divine control and involvement. Because women may view an androgynous God as embodying both masculine (e.g., controller) and feminine (e.g., healer) qualities (Nelson, Cheek, \& Au, [35]), an androgynous God who takes on both male and feminine qualities may be viewed as having just as much control and involvement in their lives as those who believe God to be male. More research on gendered God concepts will shed light on the relationship between androgynous conceptualizations of God and beliefs and attitudes.

Last, unlike Study 1, in Study 2 we found that individuals with male conceptualizations of God were higher in RWA-Conventionalism than individuals without male conceptualizations of God. Again this may be due to the differences in the demographics of both samples. Whereas Study 1 included millennial, college-age students, Study 2's national demographic was more representative in age and religion of the general public.

\section{General discussion}

The present work examined the relationship between gendered conceptualizations of God and beliefs regarding divine control, divine involvement, religious fundamentalism, and RWA. Based on recent theorizing that male representations of God reflect how people perceive power, ability, status, and 
hierarchy, we predicted that individuals who believe God to be male would also believe that God had more involvement and control in their lives and would be higher in both religious fundamentalism and RWA. Across two studies we found evidence that male representations of God were associated with higher levels of divine control, divine involvement, religious fundamentalism, and RWAAuthoritarianism (Studies 1 and 2), RWA-Submission (Studies 1 and 2), and RWA-Conservatism (Study 2 ), supporting our predictions. Our results make an important contribution to the literature on how gendered God concepts are associated with certain beliefs and attitudes. Whereas past work in this area has typically focused on how gendered representations of God influence beliefs and attitudes related to politics and gender traditionalism, the present study focused on the relationship between gendered God concepts and other religious beliefs and rigid ideologies (e.g., RWA).

Given that beliefs regarding divine control and divine involvement have been theorized to be linked to gendered beliefs regarding agency and control (Daly, [14]; Steenwyk, Atkins, Bedics, \& Whitley, [45]) and RWA is associated with submission to perceived legitimate figures of authority, these findings have a number of implications regarding men and women's self-esteem, as well as individuals' judgment and decision making in both religions and nonreligious domains.

For example, past research has shown that certain God concepts are linked to psychological well-being. Steenwyk et al. ([45]) found that conceptualizing God as controlling can influence feelings of hopelessness for both men and women. They found that having a mental representation of God as controlling leads to fewer experiences of hopelessness for men but leads to feelings of more hopelessness for women. If male conceptualizations of God are associated with beliefs about God having more control and involvement in one's life, then women with male conceptualizations of God may experience more feelings of hopelessness, whereas men may experience fewer feelings of hopelessness. Steenwyk and colleagues argued that because a controlling representation of God may reflect gender-role stereotypes suggesting men should be independent, in control, knowledgeable, and in command whereas women should be dependent, submissive, uninformed, and controlled, a controlling (or male) representation of God may symbolize women's submissiveness and lack of control, thus increasing their sense of hopelessness. It is important to note, however, that women in Study 2 (i.e., national sample) who believed God to be androgynous also believed that God had more control and involvement in their lives than men with the same gender concept. This raises an important question regarding the potential different consequences associated with believing in a male God who has a fair amount of control and involvement in one's life versus an androgynous God who has a fair amount of control and involvement in one's life. Although this has not been explored directly, past research does provide some initial answers for the question. Aldredge-Clanton ([ 1]) found that women who believed God to be androgynous or a being that transcends gender showed significantly higher levels of autonomy, self-confidence, dominance, and creativity than women who conceptualized God as solely male. This suggests that the psychological consequences of believing that God is controlling and male are different than the psychological consequences of believing that God is controlling and androgynous; however, future research in this area is necessary before drawing any conclusions.

Another implication of the present work speaks to the role that male conceptualizations of God may play in adherence to individuals in positions of authority, especially men in positions of religious 
authority (e.g., pastors, priest). Recall that we found that individuals with male conceptualizations of God also had higher levels of RWA. Given that RWA is characterized as submission to perceived legitimate authorities and adherence to societal conventions and norms (Altemeyer \& Hunsberger, [ 2]; Hall, Matz, \& Wood, [22]; McCleary, Quillivan, Foster, \& Williams, [34]), individuals who believe God to be male may be particularly likely to submit to male religious authority figures and be less willing to confront and challenge these individuals. Indeed, qualitative research with Evangelical women does offer some initial support for this notion. Gallagher ([19]) found that many female Evangelicals who conceptualized God as male believed that men are a direct representation of God and that women who defy men's authority are defying God. In many child sexual abuse cases involving Catholic priests, members of the church, including nuns and mothers of the victims, were aware of the abuse but did not report these actions to authorities (Survivors Network of those Abused by Priests, [46]). The failure to report the abuse of children by Catholic priests may be explained in part by individuals submitting to and not wanting to challenge male authority, especially authority that is likened to God.

In addition, the finding that a male conceptualization of God is positively correlated with RWA may help shed light on recent research that has found that male conceptualizations of God are related to more support for traditional gender roles (Cassese \& Holman, [10]; Whitehead, [49]), higher levels of political conservatism (Cassese \& Holman, [10]), and more negative attitudes toward same-sex marriages (Whitehead, [50]). RWA may mediate the relationship between male God concepts and these attitudes and ideologies given that RWA is strongly correlated with endorsement of political conservatism, less support for social equality, and prejudice against a wide variety of ethnic and sexual minorities (Jost, Glaser, Sulloway, \& Kruglanski, [30]; Sibley \& Duckitt, [43]). Furthermore, although tangentially related to the present work, it has been theorized that at the core of conservative ideology is the notion that society functions best with a strict father (Lakoff, [33]). This contrasts with the idea that, at the core of more liberal ideology, society functions best with having a nurturing parent of either gender.

\section{Limitations and future directions}

The present study is not without limitations. First, the samples across both studies were limited to the United States and were predominantly Christian. We therefore do not know how the results of this study would apply to Christians outside the United States, individuals of different faiths within the United States (e.g., Judaism, Islam), and individuals who practice polytheistic religions both within and outside the United States. Because the gender concept of God can be dogmatic and/or culture specific, it could be predicted that data collected from samples of people who practice Abrahamic religions, which almost invariably refer to God with male gendered pronouns (e.g., the Father and the Son; He), would replicate the results from the present study. However, based on the current available research it is unclear what to expect data would look like from samples that practice Eastern religions. For example, in Hinduism, a male God is often accompanied by a female consort, such as Shiva and Parvati, and in Tibetan Buddhism female gods such as Khadroma and Tara are exceptionally popular. Future research is necessary to determine if the association between male conceptualizations of God, beliefs of divine control and divine involvement, and rigid ideologies is unique to Christianity or if it generalized to other religions as well. 
A second limitation of present study is that any conclusions drawn from our results must be taken with some reservations, given that our study is not a true experiment. We did not manipulate any God concepts but looked at mean differences. We do not know if male conceptualizations of God cause people to believe that God has more control and involvement in their lives or if male conceptualizations of God cause increases in individuals' religious fundamentalism and RWA. It could be that the direction of the relationship between these constructs is in the other direction (e.g., those high in RWA relative to those low in RWA are more likely to believe God is a man). However, past research regarding the relationship between religiosity and RWA does seem to suggest that religiosity precedes authoritarian beliefs (Wink, Ciciolla, Dillon, \& Tracy, [51]).

With that said, to advance the current state of gendered God concept research, researchers will need to employ experimental methodologies to establish a causal relationship between male conceptualizations of God and the psychological constructs explored in this article and elsewhere. With that advent of priming methodologies in religious cognition research (e.g., Howard \& Sommers, [27]) researchers can explore a number of research questions.

\section{Conclusions}

The association between gendered God concepts and various social and political beliefs, attitudes, and behaviors is of growing interest to behavioral scientists. The current study provides evidence that male conceptualizations of God are associated with beliefs regarding the amount of control and involvement God has in one's life, as well as rigid ideologies such as religious fundamentalism and RWA. The present study's findings add to our understanding of the complex relationship between religiosity and social beliefs and attitudes while identifying additional research questions for future exploration.

\section{References}

Aldredge-Clanton, J. (2001). In whose image? God and gender. New York, NY: Crossroad.

Altemeyer, B., \& Hunsberger, B. (1992). Authoritarianism, religious fundamentalism, quest and prejudice. International Journal for the Psychology of Religion, 2, 113-133. doi:10.1207/s15327582ijpr0202_5

Altemeyer, B., \& Hunsberger, B. (2004). A revised religious fundamentalism scale: The short and sweet of it. International Journal for the Psychology of Religion, 14, 47-54. doi:10.1207/s15327582ijpr1401_4

Altemeyer, R. A. (1981). Right-wing authoritarianism. Winnipeg, Canada: University of Manitoba Press. Altemeyer, R. A. (1988). Enemies of freedom: Understanding right-wing authoritarianism. San Francisco, CA: Jossey-Bass.

Altemeyer, R. A. (1996). The authoritarian specter. Cambridge, MA: Harvard University Press.

Atran, S., \& Norenzayan, A. (2004). Religion's evolutionary landscape: Counterintuition, commitment, compassion, communion. Behavioral and Brain Sciences, 27, 713-770. doi:10.1017/S0140525X04000172

Bader, C., \& Froese, P. (2005). Images of God: The effect of personal theologies on moral attitudes, political affiliation, and religious behavior. Interdisciplinary Journal of Research on Religion, 1, 1-24. 
Buhrmester, M., Kwang, T., \& Gosling, S. D. (2011). Amazon's Mechanical Turk a new source of inexpensive, yet high-quality, data? Perspectives on Psychological Science, 6, 3-5. doi:10.1177/1745691610393980

Cassese, E. C., \& Holman, M. R. (2017). Religion, gendered authority, and identity in American politics. Politics and Religion, 10, 31-56. doi:10.1017/S1755048316000407

Christ, C. P. (2012). Why women, men and other living things still need the Goddess: Remembering and reflecting 35 years later. Feminist Theology, 20, 242-255. doi:10.1177/0966735012436897

Clark, K. J. (2014). God and the good life. In K. J. Clark (Ed.), Religion and the sciences of origins (pp. 153-164). New York, NY: Palgrave Macmillan.

Crawford, J. T., Brandt, M. J., Inbar, Y., \& Mallinas, S. R. (2016). Right-wing authoritarianism predicts prejudice equally toward "gay men and lesbians" and "homosexuals". Journal of Personality and Social Psychology, 111(2), e31-e45. doi:10.1037/pspp0000070

Daly, M. (1973). Beyond God the father: Toward a philosophy of women's liberation. Boston, MA: Beacon Press.

Davis, E. B., Moriarty, G. L., \& Mauch, J. C. (2013). God images and god concepts: Definitions, development, and dynamics. Psychology of Religion and Spirituality, 5, 51-60. doi:10.1037/a0029289

Featherstone, R. (2001). Compliance as dissidence: Young Catholics and sexual ethics. Sociological Focus, 34, 139-154. doi:10.1080/00380237.2001.10571188

Froese, P., \& Bader, C. D. (2007). God in America: Why theology is not simply the concern of philosophers. Journal for the Scientific Study of Religion, 46, 465-481. doi:10.1111/jssr.2007.46.issue-4

Froese, P., \& Bader, C. D. (2010). America's four Gods. New York, NY: Oxford University Press.

Gallagher, S. K. (2003). Evangelical identity and gendered family life. New Brunswick, NJ: Rutgers University Press.

Greeley, A. M. (1988). Evidence that a maternal image of God correlates with liberal politics. Sociology and Social Research, 72, 150-154.

Greeley, A. M. (1993). Religion and attitudes toward the environment. Journal for the Scientific Study of Religion, 32, 19-28. doi:10.2307/1386911

Hall, D. L., Matz, D. C., \& Wood, W. (2010). Why don't we practice what we preach? A meta analytic review of religious racism. Personality and Social Psychology Review, 14(1), 126-139. doi:10.1177/1088868310364151

Hall, T. W., \& Fujikawa, A. M. (2013). God image and the sacred. In K. I. Pargament, J. J. Exline, \& J. W. Jones (Eds.), APA handbook of psychology, religion, and spirituality. Volume 1: Context, theory, and research (pp. 277-292). Washington, DC: American Psychological Association.

Harris Poll. (2003, October 16). Most Americans believe in God but there is no consensus on his/her gender, form or degree of control over events. Retrieved from http://media.theharrispoll.com/documents/Harris-Interactive-Poll-Research-Most-AmericansBelieve-in-God-but-There-Is-No-Cons-2003-10.pdf

Harris Poll. (2013, December 16). Americans' belief in God, miracles and heaven declines. Retrieved from http://www.theharrispoll.com/health-andlife/Americans\%5f\%5fBelief\%5fin\%5fGod\%5f\%5fMiracles\%5fand\%5fHeaven\%5fDeclines.html 
Heiphetz, L., Lane, J. D., Waytz, A., \& Young, L. L. (2015). How children and adults represent God's mind. Cognitive Science, 39, 1-24. doi:10.1111/cogs.12232

Howard, S., \& Sommers, S. R. (2017). Exposure to White religious iconography influences Black individuals' intragroup and intergroup attitudes. Cultural Diversity and Ethnic Minority Psychology, 23(4), 508-515. doi:10.1037/cdp0000152

Howard, S., \& Sommers, S. R. (2017). White religious iconography increases anti-Black attitudes. Psychology of religion and spirituality. [Advance online publication].

Jensen, L. A. (2009). Conception of God and the Devil across the lifespan: A cultural developmental study of religious liberals and conservatives. Journal of the Scientific Study of Religion, 48, 121-145. doi:10.1111/j.1468-5906.2009.01433.x

Jost, J. T., Glaser, J., Sulloway, F., \& Kruglanski, A. W. (2003). Political conservatism as motivated social cognition. Psychological Bulletin, 129, 339-375. doi:10.1037/0033-2909.129.3.339

Kelley, J., \& De Graaf, N. D. (1997). National context, parental socialization, and religious belief: Results from 15 nations. American Sociological Review, 62, 639-659. doi:10.2307/2657431

LaBouff, J. P., Rowatt, W. C., Johnson, M. K., \& Finkle, C. (2012). Differences in attitudes towards outgroups in a religious and non-religious context in a multinational sample: A situational context priming study. The International Journal for the Psychology of Religion, 22, 1-9. doi:10.1080/10508619.2012.634778

Lakoff, G. (2014). Don't think of an elephant! Know your values and frame the debate: The essential guide for progressives. White River Junction, VT: Chelsea Green.

McCleary, D. F., Quillivan, C. C., Foster, L. N., \& Williams, R. L. (2011). Meta-analysis of correlational relationships between perspectives of truth in religion and major psychological constructs. Psychology of Religion and Spirituality, 3, 163-180. doi:10.1037/a0022208

Nelson, H. M., Cheek, N. H., Jr., \& Au, P. (1985). Gender differences in images of God. Journal for the Scientific Study of Religion, 24, 396-402. doi:10.2307/1385990

Nowell, C., \& Laufer, D. (1997). Undergraduate cheating in the fields of business and economics. Journal of Economic Education, 28, 3-12. doi:10.1080/00220489709595901

Pew Research Center. (2016, March 22). The gender gap in religion around the world. Retrieved from http://www.pewforum.org/2016/03/22/the-gender-gap-in-religion-around-the-world/

Randolph-Seng, B., \& Nielsen, M. E. (2007). Honesty: One effect of primed religious representations. The International Journal for the Psychology of Religion, 17, 303-315. doi:10.1080/10508610701572812

Rowatt, W. C., Shen, M. J., LaBouff, J. P., \& Gonzalez, A. (2013). Religious fundamentalism. right-wing authoritarianism, and prejudice: Insights from meta-analyses, implicit social cognition, and social neuroscience. In R. F. Paloutzian \& C. L. Park (Eds.), Handbook of the psychology of religion and spirituality (2nd ed., pp. 457-475). New York, NY: Guilford Press.

Schieman, S. (2010). Socioeconomic status and beliefs about God's influence in everyday life. Sociology of Religion, 71, 25-51. doi:10.1093/socrel/srq004

Schieman, S., Pudrovska, T., \& Milkie, M. A. (2005). The sense of divine control and the self-concept: A study of race differences in late life. Research on Aging, 27, 165-196.

doi:10.1177/0164027504270489 
Shariff, A. F., \& Norenzayan, A. (2011). Mean Gods make good people: Different views of God predict cheating behavior. International Journal for the Psychology of Religion, 21, 85-96. doi:10.1080/10508619.2011.556990

Sibley, C. G., \& Duckitt, J. (2008). Personality and prejudice: A meta-analysis and theoretical review. Personality and Social Psychology Review, 12, 248-279. doi:10.1177/1088868308319226

Smith, R. E., Wheeler, G., \& Diener, E. (1975). Faith without works: Jesus people, resistance to temptation, and altruism. Journal of Applied Social Psychology, 5, 320-330. doi:10.1111/jasp.1975.5.issue-4

Steenwyk, S. A. M., Atkins, D. C., Bedics, J. D., \& Whitley, B. E., Jr. (2010). Images of God as they relate to life satisfaction and hopelessness. International Journal for the Psychology of Religion, 20, 85-96. doi:10.1080/10508611003607942

Survivors Network of those Abused by Priest. (2012). Abuse by women religious (nuns and sisters). Retrieved from http://www.snapnetwork.org/nun\%5fabuse?page=4

Trzebiatowska, M., \& Bruce, S. (2012). Why are women more religious than men? Oxford, U.K.: Oxford University Press.

Village, A. (2005). Factors shaping biblical literalism: A study among Anglican Laity.". Journal of Beliefs and Values, 26, 29-38. doi:10.1080/13617670500047566

Whitehead, A. L. (2012). Gender ideology and religion: Does a male image of God matter? Review of Religious Research, 54, 139-156. doi:10.1007/s13644-012-0056-3

Whitehead, A. L. (2014). Politics, religion, attribution theory, and attitudes toward same-sex unions. Social Science Quarterly, 95(3), 701-718. doi:10.1111/ssqu.2014.95.issue-3

Wink, P., Ciciolla, L., Dillon, M., \& Tracy, A. (2007). Religiousness, spiritual seeking, and personality: Findings from a longitudinal study. Journal of Personality, 75, 1051-1070.

\section{Footnotes}

There is a recent debate among some researchers calling for behavioral scientists who study religion to use the terms God concepts and God images to distinctively convey certain meaning (Davis et al., [15]; Hall \& Fujikawa, [23]). They argue that God concepts reflect explicit, cognitive, doctrinal representations of the Divine, whereas God images reflect implicit, affect-laden, experiential representations of the Divine. However, these terms, as well as others (e.g., God representations, God perceptions), are still used interchangeably in the literature. Because there is no widespread consensus on what terminology should be adopted, we use both God concept and God representations.

This also included individuals who believed in a female God $(n=4)$. Given the small number of individuals who believed in a female God, we combined this condition with individuals who have female + male (androgynous) conceptualizations of God. However, the results remain the same when individuals with female God concepts are excluded. 
